\title{
REACTIONS OF ORGANOGERMYLENES GENERATED BY PHOTOLYSIS OF 7-GERMANORBORNADIENES AND CYCLOHEXAGERMANES WITH ORGANIC HALIDES AND TRIMETHYLTIN CHLORIDE
}

\author{
Michiyo Adachi, ${ }^{1}$ Kunio Mochida, ${ }^{\star 1}$ Masanobu Wakasa, ${ }^{2}$ and Hisaharu Hayashi ${ }^{2}$ \\ ${ }^{1}$ Department of Chemistry, Faculty of Science, Gakushuin University, 1-5-1 Mejiro, \\ Toshima-ku, Tokyo 171-8588, Japan \\ ${ }^{2}$ The Institute of Physical and Chemical Research, Wako, Saitama 351-0106, Japan
}

\begin{abstract}
Reactions of organogermylenes, $\mathrm{R}_{2} \mathrm{Ge}: \quad\left(\mathrm{R}=\mathrm{Me}\right.$ and $\left.{ }^{\mathrm{i}} \mathrm{Pr}\right)$, generated by photolysis of 7germanorbornadienes and cyclohexagermanes with organic halides ( $\left.R^{\prime} X\right)$ were examined by chemical trapping experiments and CIDNP measurements. The organogermylenes reacted quantitatively with polyhalomethanes $\left(\mathrm{XCCl}_{3}, \mathrm{X}=\mathrm{Cl}, \mathrm{Br}\right)$ and benzyl bromide to give the corresponding abstraction products together with polyhaloethanes and bibenzyl, respectively. With trimethyltin chloride the organogermylenes afforded effectively the insertion products.

\section{Introduction}

The mechanistic study of organogermylenes, carbene analogues containing a divalent germanium atom, is currently an active field [1-4]. The concerted and non-concerted radical mechanisms in the thermal and photochemical reactions of organogermylenes are discussed by Neumann and co-workers $[2,5,6]$, Gaspar and co-workers [7], Egorov and Nefedov [8], Ando and co-workers [9], and our groups [10] using chemical trapping experiments, laser flash photolysis, matrix isolation techniques, and CIDNP techniques. The most used organogermylenes in mechanistic study are dimethylgermylene generated thermally and photochemically from 7,7-dimethyl-7-germanorbornadienes [4]. Dodecamethylcychohexa-germane is also a convenient photochemical precursor of dimethylgermylenes [11]. However, very little is known about the systematic study of the reactivity of organogermylenes generated photochemically from different precursors towards organic substrates. In this paper the results of our study of photochemical reactions of organogermylenes, $\mathrm{R}_{2} \mathrm{Ge}$ : $\left(\mathrm{R}=\mathrm{Me},{ }^{\mathrm{P}} \mathrm{Pr}\right)$, generated from 7-germanorbornadienes and cyclohexagermanes with several organic halides ( $\left.\mathrm{R}^{\prime} \mathrm{X}\right)$ such as polyhalomethanes $\left(\mathrm{CCl}_{4}, \mathrm{BrCCl}_{3}, \mathrm{CHCl}_{3}, \mathrm{CH}_{2} \mathrm{Cl}_{2}\right)$, benzyl bromide $\left(\mathrm{PhCH}_{2} \mathrm{Br}\right)$, and trimethyltin chloride $\left(\mathrm{Me}_{3} \mathrm{SnCl}\right)$ by chemical trapping experiments and CIDNP measurements are examined.
\end{abstract}

\section{Experimental}

${ }^{1} \mathrm{H}$ spectra were recorded with a Varian Unity-Inova $400 \mathrm{MHz}$ NMR and a JEOL JNMFX $100 \mathrm{MHz} \mathrm{NMR}$. The GC-MS spectra were recorded using a JEOL JMS-DX 303 mass spectrometer. Gas chromotagraphy was done on a Shimadzu GC 8A with $1 \mathrm{~m} \mathrm{20 \%} \mathrm{SE30} \mathrm{and} \mathrm{30 \%} \mathrm{Apiezon} \mathrm{L} \mathrm{columns.}$

Materials. Dimethyldichlorogermane $\left(\mathrm{Me}_{2} \mathrm{GeCl}_{2}\right)$ [12], dimethyldibromogermane $\left(\mathrm{Me}_{2} \mathrm{GeBr}_{2}\right)$ [13], diisopropyldichlorogermane $\left({ }^{\mathrm{P}} \mathrm{Pr}_{2} \mathrm{GeCl}_{2}\right)$ [14], diisopropyldibromogermane $\left({ }^{1} \mathrm{Pr}_{2} \mathrm{GeBr}_{2}\right)$ [14], 2,3-benzo-7,7dimethyl-1,4,5,6-tetraphenyl-7-germanorbornadiene [15], dodecamethylcyclohexagermane [16], and trimethyltin chloride [17], were prepared as described. Carbon tetrachloride $\left(\mathrm{CCl}_{4}\right)$, bromotrichloromethane $\left(\mathrm{BrCCl}_{3}\right)$, chloroform $\left(\mathrm{CHCl}_{3}\right)$, dichloromethane $\left(\mathrm{CH}_{2} \mathrm{Cl}_{2}\right)$, and benzyl bromide are commercially available. Benzene, benzene- $\mathrm{d}_{6}$, and cyclohexane- $\mathrm{d}_{12}$ were dried over calcium hydride and distilled under argon.

Preparation of 2,3-benzo-7,7-diisopropyl-1,4,5,6-tetraphenyl-7-germabenzonorborna-diene. 2,3-Benzo7,7-diisopropyl-1,4,5,6-tetraphenyl-7-germanorbornadiene was prepared by the reaction of 1,1-diisopropyl2,3,4,5-tetraphenyl-1-germacyclopenta-2,4-diene with benzyne as described in literature [16]. ' $\mathrm{H}$ NMR ( $\delta$ in $\left.\mathrm{C}_{6} \mathrm{D}_{6}\right) 0.94(\mathrm{~d}, \mathrm{~J}=7.5 \mathrm{~Hz}, 6 \mathrm{H}), 1.42(\mathrm{~d}, \mathrm{~J}=7.5 \mathrm{~Hz}, 6 \mathrm{H}), 1.52$ (sep., J=7.7 Hz, $\left.1 \mathrm{H}\right), 2.35$ (sep., J=7.7 Hz, 1 H), 6.90-7.66 (m, 24 H). MS, m/z 507 (1), 432 (100), 355 (10), 276 (4), 200 (2), 177 (9), 83 (8), 70 (7), $57(5)$.

Matrix isolation of 7-germanorbornadienes at $77 \mathrm{~K}$. The 7,7-diisopropyl-7-germanorbornadiene (3) (30 $\mathrm{mg}$ ) was dissolved in 3-methylpentane (3-MP) $(5 \mathrm{ml})$ and sealed in vacuo in a quartz cell connected to a Pyrex tube. The cell was introduced into an Oxford cryostat. The sample was cooled to $77 \mathrm{~K}$ and irradiated with a 110-W low-pressure Hg arc lamp. The UV spectra were recorded on a Shimadzu UV2200 spectrometer.

Photochemical reactions of 7-germanorbornadienes with organic halides and trimethyltin chloride. As a representative example, the photochemical reaction of 7,7-dimethyl-7-germabenzonorbornadiene (1) with carbon tetrachloride $\left(\mathrm{CCl}_{4}\right)$ is described. A degassed sealed Pyrex tube containing a dry benzene $(5 \mathrm{ml})$ solution of $1(0.05 \mathrm{mmol})$ and $\mathrm{CCl}_{4}(0.2-0.5 \mathrm{mmol})$ was irradiated with a high-pressure $\mathrm{Hg}$ arc lamp (450 W) for $35 \mathrm{~min}$ at $0{ }^{\circ} \mathrm{C}$. NMR, GC, and GC-MS analysis of the resulting mixture showed $\mathrm{Me}_{2} \mathrm{GeCl}_{2}(0.05$ 
mmol, $100 \%), \quad$ 1,2,3,4-tetraphenylnaphthalene $(0.05 \mathrm{mmol}, 100 \%)$, and hexachloroethane, $\mathrm{Cl}_{6} \mathrm{C}_{2}(0.03$ mmol, 57\%). $\mathrm{Me}_{3} \mathrm{SnGeMe}_{2} \mathrm{Cl}$ : ${ }^{1} \mathrm{H}$ NMR $\left(\delta\right.$ in $\left.\mathrm{C}_{6} \mathrm{D}_{6}\right) 0.27(\mathrm{~s}, 9 \mathrm{H}), 0.76(\mathrm{~s}, 6 \mathrm{H}) . \quad \mathrm{MS}, \mathrm{m} / \mathrm{z} 302\left(\mathrm{M}^{+}\right)$. $\mathrm{Me}_{3} \mathrm{SnGe}^{\prime} \mathrm{Pr}_{2} \mathrm{Cl}$ : ${ }^{1} \mathrm{H}$ NMR $\left(\delta\right.$ in $\left.\mathrm{C}_{6} \mathrm{D}_{6}\right) 0.38(\mathrm{~s}, 9 \mathrm{H}), 0.93(\mathrm{~d}, \mathrm{~J}=7.5 \mathrm{~Hz}, 6 \mathrm{H}), 1.42(\mathrm{~d}, \mathrm{~J}=7.5 \mathrm{~Hz}, 6 \mathrm{H}), 1.53$ (sep., J=7.5 Hz, $1 \mathrm{H}$ ), 2.35 (sept., J=7.5 Hz, $1 \mathrm{H}$ ). MS, m/z $356\left(\mathrm{M}^{+}\right)$.

Photochemical reactions of dodecamethylcyclohexagermane with organic halides. As a representative example, the photochemical reaction of dodecamethylcyclohexagermane (3) with $\mathrm{CCl}_{4}$ is described. A degassed sealed quartz tube containing a dry benzene $(5 \mathrm{ml})$ of $\mathbf{3}(0.05 \mathrm{mmol})$ and $\mathrm{CCl}_{4}(0.5 \mathrm{mmol})$ was irradiated with a low-pressure $\mathrm{Hg}$ arc lamp $(110 \mathrm{~W})$ for $1 \mathrm{~h}$ at room temperature. NMR, GC, and GC-MS analysis of the resulting mixture showed $\mathrm{Me}_{2} \mathrm{GeCl}_{2}(0.05 \mathrm{mmol}, 100 \%)$, decamethylcyclopentagermane $(0.04$ mmol, $80 \%), \mathrm{Cl}_{6} \mathrm{C}_{2}(0.02 \mathrm{mmol}, 39 \%)$, and unidentified products.

${ }^{1} \mathrm{H}$ CIDNP measurements of the photolysis of 7,7-diisopropyl-7-germabenzonorbormadiene with benzyl bromide. A cyclohexane- $\mathrm{d}_{12}(0.5 \mathrm{ml})$ solution of 7,7-diisopropyl-7-gerambenzonorbornadiene (2) $(60 \mathrm{mg})$ and benzyl bromide $(19 \mathrm{mg}$ ) was deoxygenated in a $5 \mathrm{~mm}$ quartz NMR tube by bubbling pure argon gas for 10 min before irradiation. NMR spectra were measured before and after irradiation. The details of the CIDNP apparatus and measurements have been published elsewhere [18]. The 500-W high pressure $\mathrm{Hg}$ arc lamp light was focussed onto the NMR detecting region of a sample cell through a water filter and quartz lenses. The sampling and the irradiation time were controlled by a DG 535 pulse generator (Stanford Research Systems, Inc) with an electrical shutter. The irradiation period was $7 \mathrm{~s}$ prior to the applied RF pulse. The total interval including the signal sampling was $8 \mathrm{~s}$. Usually, the signal was accumulated 4-8 times.

\section{Results and Discussion}

Electronic Absorption Spectra of Organogermylenes. Germylenes were generated by UV photolysis at $254 \mathrm{~nm}$ of 7 -germanorbornadienes $(1,2)$ or dodecamethylcyclohexagermane $(3)$.

Irradiation of a cyclohexane solution of 7,7-diisopropyl-7-germanorbornadiene (2) and 2,3-dimethyl-1,3butadiene with a high-pressure $\mathrm{Hg}$ arc lamp at $0{ }^{\circ} \mathrm{C}$ produced 1,1-diisopropyl-3,4-dimethyl-1-germacyclopent3 -ene in $89 \%$ yield. The formation of 1 -germacyclopent-3-ene can be rationalized by the reaction of diisopropylgermylene with 2,3-dimethyl-1,3-butadiene [4].

Irradiation of 2 in 3-MP at $77 \mathrm{~K}$ for $10 \mathrm{~min}$ led to a yellow coloration of the glass and to an absorption at $450 \mathrm{~nm}$. When the 3-MP glass was melted, the 450-nm maximum rapidly diminished. UV spectra of dimethylgermylene generated by photolysis of 1 and 3 in 3-MP at $77 \mathrm{~K}$ have been reported to be at $420 \mathrm{~nm}$ [19] and $450 \mathrm{~nm}[16]$, respectively.

Chemical Trappings. Photochemical reactions of organogermylenes, $\mathrm{R}_{2} \mathrm{Ge}$ : $\left(\mathrm{R}=\mathrm{Me}\right.$ and $\left.{ }^{\mathrm{P}} \mathrm{Pr}\right)$ with several organic halides $\left(R^{\prime} X\right)$ were examined. The results are summarized in Tables 1 and 2.

On irradiation of benzene solutions of 7-germabenzonorbornadienes ( 1 and 2 ) containing organic halides ( $\left.{ }^{\prime} \mathrm{X}\right)$ such as $\mathrm{XCCl}_{3}\left(\mathrm{X}=\mathrm{Cl}, \mathrm{Br}\right.$ ) and $\mathrm{PhCH}_{2} \mathrm{Br}$ with a high-pressure $\mathrm{Hg}$ arc lamp through a Pyrex filter at 0 ${ }^{\circ} \mathrm{C}$ for $35 \mathrm{~min}-1 \mathrm{~h}$, dihalogermanes $\left(\mathrm{R}_{2} \mathrm{GeX}_{2}\right), 1,2,3,4$-tetraphenylnaphthalene, and coupling products $\left(\mathrm{R}^{\prime}-\mathrm{R}^{\prime}\right)$ were formed in high yields as shown in Table 1. Similarly, benzene solutions of dodecamethylcyclohexagermane (3) containing R'X $\left(\mathrm{CCl}_{4}, \mathrm{BrCCl}_{3}, \mathrm{PhCH}_{2} \mathrm{Br}\right)$ were irradiated with a low pressure $\mathrm{Hg}$ arc lamp at room temperature for $1-1.5 \mathrm{~h}$ to give quantitatively $\mathrm{R}_{2} \mathrm{GeX}_{2}$ together with decamethylcyclopentagermane, $R^{\prime}-R^{\prime}$, and unidentified products as shown in Table 1 . The yields of the products in Table 1 are almost independent of the concentrations of R'X (2.5-10 eq. for 1-3), solvent used (benzene or cyclohexane), and the irradiation times (1-2 h).

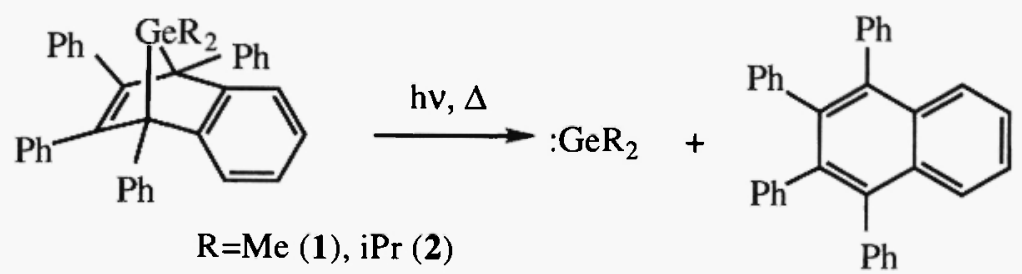<smiles>CC(C)C1C(C)C(C)C(C(C)C)C1C(C)C</smiles>

3

Prolonged irradiation of 3 led to increased yields of $\mathrm{Me}_{2} \mathrm{GeCl}_{2}$, octamethylcyclotetragermane, and 2,2,3,3,4,4,5,5-octamethyl-1-oxa-2,3,4,5-tetragermacyclopentane. With $\mathrm{CHCl}_{3}$ and $\mathrm{CH}_{2} \mathrm{Cl}_{2}$ organogermylenes 
generated from 1-3 could not afford abstraction products, probably due to the relatively strong bond dissociation energy of $\mathrm{C}-\mathrm{Cl}$.

The formation of $\mathrm{R}_{2} \mathrm{GeX}_{2}\left(\mathrm{R}=\mathrm{Me},{ }^{\mathrm{P}} \mathrm{Pr}\right)$ may be the result of a stepwise halogen abstraction from organic halides by organogermylenes as shown in the silicon cases [20]. The radical ( $R^{\prime}$ ) generated by abstraction of organogermylenes from $R^{\prime} X$ dimerizes to $R^{\prime}-R^{\prime}$. The radical nature of the intermediate is confirmed by the formation of $R_{2} \mathrm{GeX}_{2}$ and $\mathrm{R}^{\prime}-\mathrm{R}^{\prime}$.

The formation of $\mathrm{CCl}_{3}-\mathrm{CCl}_{3}$ obtained when $\mathrm{R}_{2} \mathrm{Ge}$ : reacts with $\mathrm{BrCCl}_{3}$ reflects the bond dissociation energy of germanium-halogens: $\mathrm{Ge}-\mathrm{Br}<\mathrm{Ge}-\mathrm{Cl}$. $\left(\mathrm{BrCl}_{2} \mathrm{C}\right)_{2}$ could not be detected by GC-MS. Neumann and coworkers have reported the formation of $\mathrm{Me}_{2} \mathrm{GeCl}_{2}$ only with XCCl , and $\mathrm{Me}_{2} \mathrm{GeBr}_{2}$ and $\mathrm{PhCH}_{2}\left(\mathrm{GeMe}_{2}\right) \mathrm{Br}$ with $\mathrm{PhCH}_{2} \mathrm{Br}$ by the reaction of $\mathrm{Me}_{2} \mathrm{Ge}$ : generated photochemically from 1 [5]. However, we could not detect $\mathrm{PhCH}_{2}\left(\mathrm{GeMe}_{2}\right) \mathrm{Br}$ under our experimental conditions by NMR and GC-MS.

\begin{tabular}{|c|c|c|c|c|}
\hline Precursor & R'X & Conditions & Products (Yield/\% & )$^{a},{ }_{D}$, \\
\hline & $\mathrm{CCl}$ & $h v>300 \mathrm{~nm} 35 \mathrm{~min}$ & $\mathrm{R}_{2} \mathrm{GeX}_{100}$ & $\begin{array}{l}\mathrm{R}^{\prime}-\mathrm{R}^{\prime} \\
57.0\end{array}$ \\
\hline 2 & $H_{4}$ & hv>300 nm. $1 \mathrm{~h}$ & 100 & 39.0 \\
\hline 3 & & $\mathrm{hv}<300 \mathrm{~nm}, \mathrm{l} \mathrm{h}$ & 100 & 39.0 \\
\hline 1 & $\mathrm{BrCCl}_{3}$ & $\mathrm{hv}>300 \mathrm{~nm}, 1 \mathrm{~h}$ & $\begin{array}{l}65.0(\mathrm{X}=\mathrm{Br}) \\
2.0(\mathrm{X}=\mathrm{Cl})\end{array}$ & $57.0\left(\mathrm{R}=\mathrm{CCl}_{3}\right)$ \\
\hline 2 & " & $\mathrm{hv}>300 \mathrm{~nm}, 1 \mathrm{~h}$ & $\begin{array}{l}87.0(\mathrm{X}=\mathrm{Br}) \\
9.0(\mathrm{X}=\mathrm{Cl})\end{array}$ & $58.0\left(\mathrm{R}=\mathrm{CCl}_{3}\right)$ \\
\hline 3 & . & $\mathrm{hv}<300 \mathrm{~nm}, 1.5 \mathrm{~h}$ & $\begin{array}{l}60.0(\mathrm{X}=\mathrm{Br}) \\
40.0(\mathrm{X}=\mathrm{Cl})\end{array}$ & $52.0\left(\mathrm{R}=\mathrm{CCl}_{3}\right)$ \\
\hline $\begin{array}{l}\mathbf{1} \\
\mathbf{2} \\
\mathbf{3}\end{array}$ & $\begin{array}{l}\mathrm{PhCH}_{2} \mathrm{Br} \\
.\end{array}$ & $\begin{array}{l}\mathrm{hv}>300 \mathrm{~nm}, 1 \mathrm{~h} \\
\mathrm{hv}>300 \mathrm{~nm}, 1 \mathrm{~h} \\
\mathrm{hv}<300 \mathrm{~nm}, 1.5 \mathrm{~h}\end{array}$ & $\begin{array}{l}100 \\
94.0 \\
99.0\end{array}$ & $\begin{array}{l}36.0 \\
16.0 \\
53.0\end{array}$ \\
\hline
\end{tabular}

a) NMR yields. ${ }^{\text {b) }} \mathrm{A}$ trace amount of $\mathrm{PhCH}_{2}\left(\mathrm{Ge}^{\mathrm{i}} \mathrm{Pr}_{2}\right) \mathrm{Br}$ by NMR.

On the other hand, by photolysis of 1-3 with trimethyltin chloride $\left(\mathrm{Me}_{3} \mathrm{SnCl}\right)$ in benzene, the insertion product of organogermylenes into the $\mathrm{Sn}-\mathrm{Cl}$ bond, $\mathrm{Me}_{3} \mathrm{Sn}-\mathrm{GeR}{ }_{2} \mathrm{Cl}$, was formed in high yields. No abstraction products of $\mathrm{R}_{2} \mathrm{Ge}$ : were detected.

${ }^{\prime} H$ CIDNP Measurements. Using the pulse technique, CIDNP effects could be observed at room temperature in the reaction of 7 -germanornornadienes (2) with benzyl bromide under various conditions. During continuous UV irradiation for $7 \mathrm{~s}$ (4-8 scans), the intensities of the NMR signals due to 2 and benzyl bromide were similar to those obtained in the case of 1 . ${ }^{1} \mathrm{H}$ CIDNP signals have been observed in the reactions of 1 with $\mathrm{CCl}_{4}, \mathrm{BrCCl}_{3}$, benzyl bromide, and $\mathrm{Me}_{3} \mathrm{SnCl}[2,5,21]$.

Table 2. Reactions of Organogermylenes, $R_{2} G e$ : $(R=M e, ~ ' P r)$ and

Precursor

1

2

3

a) NMR yields.
Trimethyltin Chloride Conditions

$\mathrm{hv}>300 \mathrm{~nm}, 1 \mathrm{~h}$

$\mathrm{h} v>300 \mathrm{~nm}, 1 \mathrm{~h}$

$\mathrm{h} v<300 \mathrm{~nm}, 1 \mathrm{~h}$

Reaction Mechanism. From these chemical trapping experiments and 'H CIDNP measurements previously reported and examined in this study, we propose scheme 1 as one possible reaction pathway under these experimental conditions.

With polyhalomethanes $\left(\mathrm{XCCl}_{3}\right)$, benzyl bromide, and $\mathrm{Me}_{3} \mathrm{SnCl}$, ' $\mathrm{H}$ CIDNP signals have been observed by Neumann's and Egorov's groups [2, 5, 21]. Confirming CIDNP evidence has been gained from insertion of $\mathrm{R}_{2} \mathrm{Ge}$ : into the $\mathrm{C}-\mathrm{X}$ bonds of $\mathrm{XCCl}_{3}$, benzyl bromide, and $\mathrm{Me}_{3} \mathrm{SnCl}$. The insertion here is a radical abstraction-recombination procedure. However, no insertion products of $\mathrm{R}_{2} \mathrm{Ge}$ : into $\mathrm{C}-\mathrm{X}$ bonds of $\mathrm{XCCl}_{3}$ and benzyl bromide were formed under these experimetal conditions as shown in Table 1. The ratio of yields of $\mathrm{R}_{2} \mathrm{GeX}_{2}$ vs. $\mathrm{R}^{\prime}-\mathrm{R}^{\prime}$ is roughly 1.8-2.6 for $\mathrm{CCl}_{4}, 1.2-1.9$ for $\mathrm{BrCCl}_{3}$, and 1.9-5.9 for $\mathrm{PhCH}_{2} \mathrm{Br}$. These product ratios may be explained both by the abstraction-recombination process and by the two-step radical abstraction process with free $R_{2} G e$ :. Thus, organogermylenes $R_{2} G e$ : abstract a halogen from $R^{\prime} X$ to give a halogermyl $\left(\mathrm{R}_{2} \mathrm{XGe}\right)$ and an organic radical $\left(\mathrm{R}^{\prime}\right)$. $\mathrm{R}_{2} \mathrm{XGe}$ abstracts furthermore a halogen from organic halides to produce a dihalogermane $\left(\mathrm{R}_{2} \mathrm{GeX}_{2}\right)$ and $\mathrm{R}^{\prime}$. The radical $\mathrm{R}^{\prime}$ generated by abstraction of $\mathrm{R}_{2} \mathrm{Ge}$ : from $\mathrm{R}^{\prime} \mathrm{X}$ dimerizes to R'-R'. 




Scheme 1.

References

[1] P. P. Gaspar, in Reactive Intermediates, M. Jones, R. A. Moss Eds., John Wiley \& Sons, vol. 1, 1978, vol. 2, 1981, vol 3, 1985.

[2] W. P. Neumann, Chem. Rev., 91, 311 (1991).

[3] P. Riviere, M. R-Baudet, and J. Satge, in Comprehensive Organometallic Chemistry, G. W. Wilkinson, F. G. A. Stone, and E. W. Abel, Pergamon Press, vol. 2, Chapt. 10 (1982).

[4] P. Riviere, M. R-Baudet, and J. Satge, in Comprehensive Organometallic Chemistry, G. W. Wilkinson, F. G. A. Stone, and E. W. Abel, Pergamon Press, vol. 2, Chapt. 5 (1995).

[5] For example: J. Kocher, M. Lehnig, and W. P. Neumann, Organometallics, 7, 1201 (1988) and references cited therein.

[6] H. Gorner, M. Lehnig, and M. Weisbeck, J. Photochemistry an Photobiology. A: Chemistry, 94, 157 (1996) and references cited therein

[7] For example: K. L. Bobbitt, V. M. Maloney, and P. P. Gaspar, Organometallics, 10, 2772 (1991) and references cited therein.

[8] For example: M. P. Egorov and O. M. Nefedov, Organomet. Chem., USSR, 5, 57 (1992) and references cited therein.

[9] For example: W. Ando, H. Itoh, and T. Tsumuraya, Organometallics, 8, 2759 (1989) and references cited therein.

[10] K. Mochida, K. Kimijima, H. Chiba, M. Wakasa, and H. Hayashi, Organometallics, 13, 404 (1994) and references cited therein.

[11] K. Mochida, N. Kanno, R. Kato, M. Kotani, S. Yamauchi, M. Wakasa, and H. Hayashi, J. Organomet. Chem., 415, 191 (1991).

[12] A. E. Finholt, Nucl. Sci. Abstr., 6, 617 (1957).

[13] K. Moedritzer, J. Organomet. Chem., 6, 382 (1966).

[14] H. H. Anderson, J. Am. Chem. Soc., 75, 814 (1953).

[15] M. Schriewer and W. P. Neumann, J. Am. Chem. Soc., 105, 897 (1983).

[16] E. Carberry, B. D. Dombek, and S. C. Cohen, J. Organomet. Chem., 36, 61 (1972).

[17] D. Grant and J. R. van Wazer, J. Organomet. Chem., 4, 229 (1965).

[18] M. Igarashi, T. Ueda, M. Wakasa, and Y. Sakaguchi, J. Organomet. Chem., 421, 9 (1991).

[19] W. Ando, T. Tsumuraya, and A. Sekiguchi, Chem. Lett., 1987, 317.

[20] R. Nakao, K. Oka, T. Dohmaru, Y. Nagata, and T. Fukumoto, J. Chem. Soc., Chem. Commun., 1985, 766.

[21] S. P. Kolesnikov, M. P. Egorov, A. M. Galminas, M. B. Ezhova, O. M. Nefedov, T. V. Leshina, M.

P. Taraban, A. I. Kruppa, and V. I. Maryasova, J. Organomet. Chem., 391 (1990) C1.

Received: January 27, 1999 - Accepted: February 8, 1999 Accepted in revised camera-ready format: February 17, 1999 